\title{
Post-Soviet Globalisation
}

\section{Peter van der Hoek}

Law School, Erasmus University, Rotterdam, Netherlands and Academy of Economic Studies, Bucharest, Romania

\section{ABSTRACT}

In this paper, I will focus on the current situation with regard to globalisation from a historical perspective, while I will also look at possible future developments. The term globalisation appeared in a dictionary for the first time in 1961, but the concept of globalisation is not always clear. According to Levitt (1993) a global corporation "operates (...) as if the entire world (or major regions of it) were a single entity; it sells the same things in the same way everywhere". This describes a problem of some of US companies operating in foreign markets rather than to define globalisation meaningfully. Globalisation is sometimes viewed as synonymous to internationalisation, increasing international interdependence, or as a development towards relations acquiring relatively distanceless and borderless qualities. I interpret globalisation as economic integration of countries in the world economy on the basis of open markets and free movement of goods, services, workers and capital.

JEL F 15 P 27

\section{INTRODUCTION}

The fall of the Berlin Wall in 1989 and the collapse of the Soviet Union in 1991 are the most important events of the late $20^{\text {th }}$ century. Few observers foresaw these events. As late as in February 1989 fugitives trying to escape Eastem Germany were shot. In December 1990, when I was in Tallinn, Estonia, I discussed the situation in the Soviet Union with someone who had been correspondent in Moscow for a Swedish newspaper for over ten years. Thus, he knew the Soviet Union very well. Yet, he believed that the Baltics would not be able to secede from the Soviet Union, certainly not before the turn of the century. Only nine months later, however, this was exactly what happened after the failed coup of August 1991. The Soviet Union collapsed and the Baltics regained their independence. This illustrates that predictions are very difficult to make even for those who are well informed ${ }^{1}$. 
In this paper I will not make predictions. However, I will not ignore the future either. I will focus on the current situation with regard to globalisation from a historical perspective, while I will also look at possible future developments. The term globalisation appeared in a dictionary for the first time in 1961, but the concept of globalisation is not always clear (Rodrik, 2001). In the literature concepts of globalisation can be found that sometimes seem fuzzy. According to Levitt (1993) a global corporation "operates (..) as if the entire world (or major regions of it) were a single entity; it sells the same things in the same way everywhere". This seems to describe a problem of a number of US companies operating in foreign markets rather than to define the concept of globalisation in a meaningful way. Some US companies try to sell products that were developed for the home market in foreign markets. This is a far different approach compared to many Japanese companies, which develop products for foreign markets and try to sell them in these markets. An example is the Lexus, a car that is widely sold in the US market.

Emotions sometimes seem more important than facts and rational arguments. When interviewed, demonstrators against globalisation do not always appear able to provide a meaningful definition. At the G8 meetings in Genoa in July 2001 a variety of protest groups marched on the streets to protest against globalisation. Protesters also voice their opinions on the Internet ${ }^{2}$. They seem to have some influence on official institutions as well as companies. The next G8 meeting will most likely be held in some remote place. World Bank development projects have been abandoned. Starbucks has promised to sell "fair trade" coffee beans in its coffee shops. Clothing importers in the USA settled after they had been sued over working conditions in the American commonwealth of Saipan in the Pacific. The Internet has proved an important tool in organising protest groups, which seem to have globalised faster than their target enterprises. However, a crucial question is who elected them? The governments they fight are in the end accountable to voters, but who holds the protest groups accountable?

Globalisation is sometimes used as synonymous to intemationalisation, which could be interpreted as increasing international interdependence. Globalisation is also defined as a development towards relations acquiring relatively distanceless and borderless qualities (Scholte, 1997). I interpret globalisation as economic integration of countries in the world economy on the basis of open markets and free movement of goods, services, workers and capital. This implies that products are sold across countries irrespective of distances and borders between the various outlets. Global products comprise a wide range of products including food (e.g., Kellogg's cereals), beverages (e.g., Coca-Cola), stimulants (e.g., Marlboro cigarettes), clothes (e.g., Levi's jeans), pharmaceuticals (e.g., Bayer aspirin), music recordings (e.g., Madonna), office equipment (e.g., Xerox copiers), transport vehicles (e.g., Ford), and travel services (e.g., Holiday Inn). How- 
ever, this is a qualitative characterisation rather than a quantitative and precise account of global products. The role of governments is limited with regard to this concept of globalisation.

Market principles have gained popularity in the last decades of the $20^{\text {th }}$ century. In western countries this occurred in the 1980s. Leading politicians including President Reagan in the USA and prime minister Thatcher in the UK heavily emphasised the market as the organising principle. Privatisation became a key word. In the 1990s, market principles also gained popularity in developing countries and former communist countries. After the collapse of the Soviet Union and the end of the Cold War profound changes occurred in Central and Eastern European societies. A major shift from principles of planning and control to market principles could be observed. The omnipresent fist - of the centrally planned economy was replaced with the invisible hand of the market economy in a relatively short period of time. The economic consequences of these upheavals proved to be very large. In the 1990s, GDP in Central and Eastern European countries fell dramatically. In 2000 , real GDP in the Commonwealth of Independent States (CIS) - the former Soviet republics except the three Baltic states - amounted to 55 per cent of its 1989 level. In the former East bloc - Central and Eastem Europe, the Baltics and the CIS - this figure amounted to 68 per cent (EBRD, 2000). Given the notorious allocative inefficiency of the centrally planned economies in Central and Eastern Europe, however, a fall of real GDP is not identical to a decline in the standard of living. A decrease of the production of weapons and barbed wire does not necessarily reduce the welfare of individuals. Nonetheless, the transition from centrally planned to market economies has proved to be painful.

\section{GLOBALISATION OVER TIME}

Over time the world economy has greatly benefited from globalisation. Economic theory explains that mutual gains can result from international trade if there are comparative advantages in the production of goods between nations. Dutch experience from 1850 to the end of the Napoleonic wars provides a dramatic demonstration of the way in which Western Europe interacted with the world economy in that epoch. In the mid- $18^{\text {th }}$ century Britain removed all trade and tariff restrictions unilaterally. In 1860 it had concluded reciprocal treaties for freer trade with France and other European countries, which had mostfavored nation clauses (Maddison, 2001). Historically, the first half of the $20^{\text {th }}$ century was an interruption of the move towards free trade. World War I shattered the old liberal order and international trade collapsed. This was a result of increasing protectionism during the Great Depression and the beggar-thy- 
neighbor policies. Only after World War II did the move towards free trade resume, giving rise to a sustained period of high economic growth.

Table 1 shows annual growth rates of GDP for different periods and regions. It reveals interesting developments. First, economic growth was indeed relatively high in 1950-1973 in most regions and thus also in the world. Second, in the last two centuries economic growth was typically higher in the USA compared to Western Europe, but the reverse was true in 1950-1973. Third, economic growth in Eastern Europe was typically in line with that in Western Europe with the exception of the period 1973-1990, when Eastern Europe lagged behind. Fourth, economic growth in Japan was exceptionally high in 1950-1973, when the Japanese economy grew two times as fast as the economies in the westem world. Fifth, in the $19^{4}$ century economic growth in Africa exceeded that in Asia, but lagged behind with the western world. In the first half of the $20^{\text {th }}$ century, however, economic growth in Africa was considerably higher than in Western Europe and at the same level as in the USA. In 1950-1973 economic growth in Africa was comparable to that in the westem world. In this period African growth exceeded somewhat economic growth in the USA, while it was only a little bit lower than in Europe. Sixth, economic growth in Asia was the lowest in the world until the mid-20 $0^{\text {th }}$ century. Until 1950 the annual growth rate was lower than 1 per cent, but in the post-war period it was over 5 per cent.

Table 1 Average Annual GDP Growth Rates, 1820-1998

\begin{tabular}{|l|c|c|c|c|c|}
\hline & $\mathbf{1 8 2 0 - 7 0}$ & $\mathbf{1 8 7 0 - 1 9 1 3}$ & $\mathbf{1 9 1 3 - 5 0}$ & $\mathbf{1 9 5 0 - 7 3}$ & $\mathbf{1 9 7 3 - 9 8}$ \\
\hline Western Europe & 1.65 & 2.10 & 1.19 & 4.81 & 2.11 \\
\hline Eastern Europe & 1.36 & 2.31 & 1.14 & 4.86 & 0.73 \\
\hline USA & 4.20 & 3.94 & 2.84 & 3.93 & 2.99 \\
\hline Latin America & 1.37 & 3.48 & 3.43 & 5.33 & 3.02 \\
\hline Japan & 0.41 & 2.44 & 2.21 & 9.29 & 2.97 \\
\hline Asia (excl. Japan) & 0.03 & 0.94 & 0.90 & 5.18 & 5.46 \\
\hline Africa & 0.52 & 1.40 & 2.69 & 4.45 & 2.74 \\
\hline World & 0.93 & 2.11 & 1.85 & 4.91 & 3.01 \\
\hline
\end{tabular}

Source: Maddison, 2001

Globalisation is not a new phenomenon. On the contrary, it already occurred centuries ago. Mussa (2000) points out that the extent of global economic integration through international trade today is, by some key measures, not much greater than it was a century ago. Around 1900, however, roughly two-thirds of GDP was in the goods producing sector of the typical industrial country. Now that situation is reversed, and roughly two-thirds of GDP is in the service sector of the typical industrial country. If trade shares are measured as ratios of interna- 
tional trade of goods to the output of goods production, then those shares are soon to have increased significantly from a century ago. Therefore, Mussa (2000) stresses that this supports the view that international integration of markets for goods is significantly greater today than a century ago.

The globalisation process seems to have stagnated in the first half of the $20^{\text {th }}$ century. Table 2 shows that exports decreased relative to GDP in the most important industrialised countries (plus the Netherlands) in the first half of the $20^{\text {th }}$ century. Exports rose in the second half of the $20^{\text {th }}$ century. The increase in the post-war period was much larger, however, than the decrease between the two World Wars. In terms of exports the globalisation process thus flourished in the second half of the $20^{\text {th }}$ century after a period of contraction in the first half of that century. Given the data in Tables 1 and 2, Williamson (1997) seems correct in his characterisation of the different periods. He speaks of the late $19^{\text {th }}$ century belle epoque, the dark middle years between 1914 and 1950 , and the late $20^{\text {th }}$ century renaissance. The first and last epochs were characterised by rapid growth; economic convergence as poor countries caught up with rich ones; and globalisation, marked by trade booms, mass migrations, and huge capital flows. The period 1913-1950 is associated with slow growth, a retreat from globalisation, and economic divergence.

Table 2 Exports as a percentage of GDP, 1913-1998

\begin{tabular}{|l|c|c|c|c|c|}
\hline & $\mathbf{1 9 1 3}$ & $\mathbf{1 9 2 9}$ & $\mathbf{1 9 5 0}$ & $\mathbf{1 9 7 3}$ & $\mathbf{1 9 9 8}$ \\
\hline USA & 3.7 & 3.6 & 3.0 & 4.9 & 10.1 \\
\hline Japan & 2.4 & 3.5 & 2.2 & 7.7 & 13.4 \\
\hline France & 7.8 & 8.6 & 7.6 & 15.2 & 28.7 \\
\hline Germany & 16.1 & 12.8 & 6.2 & 23.8 & 38.9 \\
\hline UK & 17.5 & 13.3 & 11.3 & 14.0 & 25.0 \\
\hline Netherlands & 17.3 & 17.2 & 12.2 & 40.7 & 61.2 \\
\hline World & 7.9 & 9.0 & 5.5 & 10.5 & 17.2 \\
\hline
\end{tabular}

Source: Maddison, 2001

History thus offers an unambiguous positive correlation between globalisation and convergence. Williamson's detailed analysis of the pre-World War I years leads him to the conclusion that the correlation seems to be causal. He concludes that globalisation was the critical factor promoting economic convergence (Williamson, 1996).

Before the collapse of the Soviet Union, Central and Eastern European countries formed an almost closed trading bloc. Trade within the Council for Mutual Economic Assistance (CMEA) dominated their international trade relations and only 
a small share of trade was conducted with the rest of the world. In particular, the Soviet Union was a closed economy with a share of trade with other CMEA countries of 90 per cent (EBRD, 1999). Exports of Eastern Europe and the former Soviet Union were not significant. In 1913, the region's share in world exports was nearly the same as its share in the world population. Its share in the world population steadily declined, whereas its share in world exports initially increased. Seven years after the collapse of the Soviet Union, however, its share in world exports was at the same level as in 1913. Thus, the relative importance of Eastern Europe and the former Soviet Union in terms of exports was equally small at the end and in the beginning of the $20^{\text {th }}$ century.

Table 3 Share of Eastern Europe's exports and population in world total, 1913-1998

\begin{tabular}{|l|c|c|c|c|}
\hline & $\mathbf{1 9 1 3}$ & $\mathbf{1 9 5 0}$ & $\mathbf{1 9 7 3}$ & $\mathbf{1 9 9 8}$ \\
\hline Exports & 4.1 & 5.0 & 7.5 & 4.1 \\
\hline Population & 4.4 & 3.5 & 2.8 & 2.0 \\
\hline
\end{tabular}

Source: Maddison, 2001

Seven years after the collapse of the Soviet Union and the CMEA the CIS countries were still to a large extent dependent on trade links with other transition countries, in particular Russia. Yet, the liberalisation of external trade in the early 1990 s led to a reallocation of trade flows away from the CMEA towards the European Union. This holds in particular for Estonia, the Czech Republic and Hungary, where exports to the European Union stood at some 50 per cent of GDP (EBRD, 2001). Trade with the rest of the world also increased, but by much less. Therefore, regionalisation seems to reflect developments in Central and Eastem Europe after the collapse of the Soviet Union more accurately than globalisation.

Regionalisation seems a growing trend. As of mid-2000 114 regional trade agreements were in effect and virtually all WTO-members are partners in at least one regional trade agreement. In the western hemisphere, the North American Free Trade Association links Canada, Mexico and the USA. In Europe, the European Union is linked by bilateral free-trade agreements to the countries in Central and Eastern Europe. A number of recent regional trade agreements in Europe and Central Asia concern the integration of countries of the former Soviet Union as well as with their neighbors. Both in Central and Latin America and in Asia the pace of conclusion of regional trade agreements continues to be rapid. Also in Africa and the Middle East regional trade agreements are growing (WTO, 2001). This growing trend of regionalisation may give rise to a tripolar view of the world, with the USA, Japan and the European Union being the three poles. However, trade groupings are not always stable in the long run. The sys- 
tem of British Commonwealth Preferences and the COMECON, for example, has collapsed, while some regional trade groupings in Africa and the Caribbean have collapsed or merged with others (Lloyd, 1992). Moreover, the European Union is the only region where the share of intra-regional merchandise trade exceeds 50 per cent. Thus, with a share of intra-regional trade of 69 per cent trade among European Union member states, trade within the European Union is more important than trade between the European Union and the rest of the world. In Asia the share of intra-regional trade amounts to 47 per cent and in North America 40 per cent (WTO, 2000). Asia and North America are thus to a lesser extent closed economies than the European Union.

\section{SCENARIOS FOR FURTHER GLOBALISATION}

One may look into the future without making any predictions by describing future developments. This is the scenario approach. The Central Planning Bureau (1999) has identified four scenarios that address the globalisation process in various ways. For that purpose it has used WorldScan, an applied general equilibrium model for the world economy focusing on economic growth in the long run and trade patterns between 12 regions $^{3}$.

The first scenario identified is the Schumpeterian World, which is optimistic on economic progress and developing regions. It emphasises globalisation tendencies and market-oriented policies in the world economy. It is based on the idea that when developing countries grow fast the linkages between OECD and nonOECD countries intensify. OECD countries specialise relatively more in goods intensive in high-skilled labor such as capital goods and services, whereas nonOECD countries specialise in consumer goods intensive in low-skilled labor. Rapid development outside the OECD area and complete liberalisation of goods and capital markets produce closer economic integration of rich and poor countries. The non-OECD share in world production increases from 23 per cent in 1995 to 42 per cent in 2020 , while the ratio of trade to GDP nearly doubles. Liberalisation of goods, services and capital allows countries to specialise, exploit economies of scale, and create competition. Moreover, open markets encourage dissemination of modern technologies in developing regions. Technology is particularly important for transition countries to help restructure their inefficient production processes inherited from the communist past.

The second scenario is the Malthusian scenario. It assumes that developing regions are unable to pursue market- and outward-oriented policies. The political situation is unstable and leads to an inward-looking attitude. The lack of trade liberalisation and neglect of infrastructure and education hurts economic growth substantially in these regions. In this scenario, people in developing regions tend 
to migrate to the OECD area and the trend towards globalisation is reversed. Despite the unfavorable market circumstances in non-OECD countries their growth rates exceed those in the OECD area. This reflects the enormous potential of these countries. However, the non-OECD share in world production shows only a modest increase to 28 per cent in 2020 . The trade restrictions imposed by nonOECD countries hamper trade significantly and the ratio of trade to GDP lowers in these countries. Japan and Western Europe reinforce their positions in the production of intermediate goods, while all OECD countries can maintain their position in the production of consumer goods. Most developing regions lose the opportunities to export agricultural goods to the OECD. China shifts to the production of consumer goods, because it faces less competition from its Asian neighbors.

The third scenario that the Central Planning Bureau (1999) identifies is the Developing scenario, which is less rosy than the first two scenarios. Growth perspectives for OECD countries are bleak, while non-OECD countries grow fast at high environmental costs. The lack of flexibility on the labor and product markets within the OECD keeps unemployment levels high and economic crises inside the OECD strengthen protectionist sentiments. Disagreement on free trade issues on agriculture and services between the USA, the European Union and Japan withholds all globalisation tendencies in the OECD. Producers reduce investment, curb research and development, and technological progress slows down. The developing countries do not face these problems and they catch up with the developed countries. Their policies are outward oriented and they go further in opening up and strengthening their markets, thereby creating their own trade blocs. They invest in infrastructure and education and rapidly copy technologies from the OECD countries. The non-OECD share in world production doubles to nearly 50 per cent As in the Schumpeterian scenario, the transition countries have to rely on technical progress, which pushes up economic growth substantially. The other regions also benefit from the increase in labor productivity by schooling and labor reallocation.

The fourth scenario is the Ecological scenario, in which producers and consumers value environmental quality and put less emphasis on economic growth. People value the consumption of local products of their own culture. Globalisation is thus not important in this respect and there are few incentives to eliminate trade barriers. The main reason for low economic growth is the lack of technological progress. The trade to GDP ratio hardly increases in the OECD area and remains constant in the non-OECD countries. The bulk of production continues to occur in the OECD area and the shift to non-OECD regions is modest. The Ecological scenario differs from the other scenarios in that the rise in demand for energy is very modest. As a result, the total emissions of $\mathrm{CO}_{2}$ are about 40 per cent lower than in the Developing scenario. Emissions in the OECD area do 
not even increase. The OECD and transition countries agree to reduce the emissions according to the Kyoto protocol, while the non-OECD countries limit the growth of energy demand by energy-efficiency improvements in production and a reduction in consumer demand. Curbed demand for energy hurts the energyexporting regions. The share of energy in total exports by the Middle East and North Africa, Sub-Saharan Africa and the former Soviet Union declines significantly. They diversify their exports to capital goods, services, and intermediate goods. The traditional exporters of agricultural goods, the USA and the rest of the OECD, improve their positions in this sector in response to the partial trade liberalisation. Asian regions now dominate the market for consumer goods. They specialise in these goods because of the relatively abundant supply of lowskilled labor. The shift in the export mix is possible due to a shift of low-skilled labor from agriculture to consumer goods. The former Soviet Union is the biggest loser in this sector and its export share vanishes.

The outcomes of the scenarios differ because different assumptions underlie the driving forces. Table 4 compares a selection of the exogenous trends and variables that the Central Planning Bureau (1999) has assumed. Technical progress is one of the most important driving forces for economic growth. If its pace is high, economies grow fast, like in the Schumpeterian and the Developing scenarios for the non-OECD countries. Most scenarios combine economic growth with increased international linkages and, consequently, trade liberalisation. Tariff reductions in agriculture and raw materials are limited to 50 per cent at the most, because these levels are very high for some regions and much less progress has so far been made in lowering these barriers. Even in the Ecological scenario some trade liberalisation occurs because regions are willing to cooperate in the field of environmental policy. Since in this scenario they are less interested in globalisation, however, trade liberalisation remains limited. The Schumpeterian scenario also features increasing capital market integration, while the extent of competition is assumed to be larger than in the other scenarios. In all scenarios with high economic growth, sustainable production is only possible if energy-efficient technologies are introduced. Therefore, OECD countries save 0.5 per cent annually on energy per unit of production in the Schumpeterian and Malthusian scenarios. Non-OECD countries even save 1 per cent in the Schumpeterian scenario. In the Ecological scenario, the environmental awareness of non-OECD countries is much higher. As a result, the energy saving amounts to 2 per cent per year with much lower dissemination of technology from the OECD countries. OECD countries save less in the Ecological scenario because technical progress is slow, which makes it more difficult to implement energy-saving technologies. The reduction in energy demand is realised by introducing energy taxes that the OECD countries impose according to the Kyoto protocol. They even agree to reduce the emissions further by 1 per cent per year after 2010. In the Ecological scenario, industrial and transition countries can 
trade in emission rights in order to realise the emission targets. The other nonOECD countries do not participate because the OECD and transition countries are mainly responsible for the abatement.

Table 4 Exogenous trends in the scenarios until 2020 (in \%)

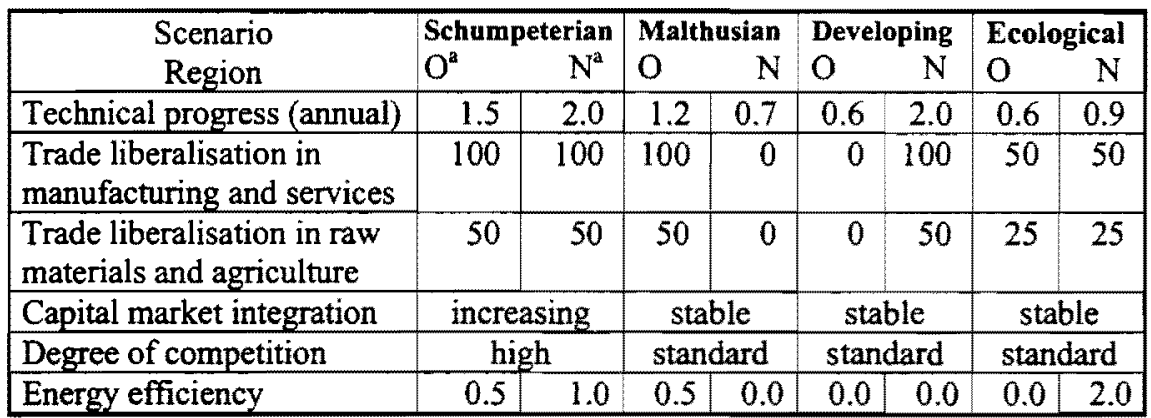

a. $\mathrm{O}=\mathrm{OECD} ; \mathrm{N}=$ non-OECD .

Source: Central Planning Bureau, 1999

The use of different exogenous trends used in the various scenarios implies a wide variation in the results. Rapid technological progress raises economic growth as is the case in the Schumpeterian and the Developing scenarios for the non-OECD countries. Table 5 shows that in high-growth scenarios GDP growth per capita is about 2 per cent in OECD countries and 6 per cent in non-OECD regions. High economic growth leads to high savings rates. Savings rates in the OECD area are generally lower than in non-OECD regions. High GDP growth also changes consumption patterns. Consumers in OECD countries spend relatively more on services. The share of food in total consumption in OECD regions is already low in 1995 (10 per cent). Therefore, the differences in the shares of food consumption in the different scenarios are small within the OECD area and range from 6.5 to 7.7 per cent. In non-OECD regions, however, these differences are considerably larger. The share of food consumption drastically declines from 26 per cent in 1995 to 12.6 or 16.7 per cent in 2020 depending on GDP growth in the scenarios. The share of consumption of services increases from 54 per cent in 1995 to 64.8 or 70.6 per cent in 2020 . 
Table 5 Summary of scenario results until 2020

\begin{tabular}{|c|c|c|c|c|c|c|c|c|}
\hline \multirow{2}{*}{$\begin{array}{l}\text { Scenario } \\
\text { Region }\end{array}$} & \multicolumn{2}{|c|}{ Schumpeterian } & \multicolumn{2}{|c|}{ Malthusian } & \multicolumn{2}{|c|}{ Developing } & \multicolumn{2}{|c|}{ Ecological } \\
\hline & $\mathrm{O}^{\mathrm{a}}$ & $\mathrm{N}^{2}$ & 0 & $\mathrm{~N}$ & $\mathrm{O}$ & $\mathrm{N}$ & & $\mathrm{N}$ \\
\hline \multicolumn{9}{|c|}{ Average annual growth between 1995 and 2020} \\
\hline GDP & 2.6 & 6.2 & 2.6 & 3.6 & 1.2 & 5.9 & 1.2 & 4.0 \\
\hline GDP per capita & 2.2 & 4.7 & 1.7 & 2.2 & 0.8 & 4.4 & 0.9 & 2.5 \\
\hline $\begin{array}{l}\text { Real producer prices } \\
\text { energy }\end{array}$ & 1.5 & 0.3 & 0.7 & 0.2 & 1.6 & -0.1 & 0.7 & 0,0 \\
\hline Emissions & 0.8 & 3.6 & 1.1 & 2.8 & 0.3 & 4.6 & 0.0 & 1.4 \\
\hline \multicolumn{9}{|c|}{ Ratios in 2020} \\
\hline $\begin{array}{l}\text { Labor reallocation as \% } \\
\text { of labor supply }\end{array}$ & & 19.1 & & 7.9 & & 18.1 & & 14.5 \\
\hline Savings rate & 17.8 & 23.5 & 17.9 & 16.6 & 14.7 & 24.4 & 14.9 & 18.9 \\
\hline Spending on services & 77.9 & 70.6 & 77.2 & 65.2 & 75.7 & 68.6 & 75.6 & 64.8 \\
\hline Spending on agriculture & 6.5 & 12.6 & 7.1 & 17.0 & 7.6 & 13.4 & 7.7 & 16.7 \\
\hline Trade to GDP & 22.9 & 43.6 & 12.5 & 22.6 & 15.0 & 25.5 & 14.6 & 24.7 \\
\hline
\end{tabular}

a. $\mathrm{O}=\mathrm{OECD} ; \mathrm{N}=$ non-OECD.

Source: Central Planning Bureau, 1999

Trade only flourishes if all countries reduce their trade barriers. Since OECD countries are endowed with high-skilled labor and capital and non-OECD countries are endowed with low-skilled labor, specialisation will increase if trade barriers between these regions are reduced or eliminated. This occurs in the Schumpeterian scenario. OECD countries have similar endowments of highskilled labor and capital, while non-OECD countries have similar endowments of low-skilled labor. Specialisation within the OECD and non-OECD regions will thus be less pronounced than between OECD and non-OECD countries given the level of aggregation in the model. Therefore, the trade to GDP ratios are fairly low in the Malthusian and Developing and also the Ecological scenarios. The high trade to GDP ratio in the Schumpeterian scenario depends on trade liberalisation and the degree of international competition.

High economic growth harms the environment. In the Schumpeterian and Malthusian scenarios emissions grow substantially but do not accelerate, due to energy-saving technologies. In the Ecological scenario demand for energy is stable due to strict environmental legislation in the OECD area. As a result, the global increase in $\mathrm{CO}_{2}$ emissions is about 20 per cent, which seems very modest given the economic development in non-OECD regions. Moreover, at the end of the scenario period emissions do not increase at all. In the Developing scenario growth of emissions does accelerate due to rapid growth in developing regions, which ignore environmental quality. As a result, emissions double in the sce- 
nario period. If energy growth is not allowed for at all, economic growth has to be low - as in the Ecological scenario - or a more strict environmental legislation is necessary. The differences in emission growth in the non-ecological scenarios are not very pronounced. In these scenarios emissions grow substantially. Whether this growth is sustainable or not is hard to say. First, the quantitative effects of pollution on the environment are unclear. Second, simulation paths of 25 years are relatively short to analyse emission paths.

\section{SUMMARY}

Globalisation is not a new phenomenon, but already occurred centuries ago. The first half of the $20^{\text {th }}$ rentury seems an interruption of the move towards free trade. After World War II, however, the move to free trade resumed and gave rise to a sustained period of high economic growth in most parts of the world. Central and Eastern Europe was an exception because this region formed an almost closed trading bloc. Though CIS countries are still to a large extent dependent on Russia, liberalisation of extemal trade in the early 1990 s led to a reallocation of trade flows away from Central and Eastem Europe towards the European Union.

The Central Planning Bureau (1999) has explored possible future developments by applying a general equilibrium model for the world economy. It has identified four scenarios:

1 The Schumpeterian World, a scenario that is optimistic on economic progress and developing regions emphasising globalisation tendencies and market-oriented policies in the world economy.

2 The Malthusian scenario, which assumes that developing regions are unable to pursue market- and outward-oriented policies.

3 The Developing scenario assuming bleak growth perspectives for the $O E C D$ area, but high growth in non-OECD countries at high environmental costs.

4 The Ecological scenario, in which producers and consumers value environmental quality and put less emphasis on economic growth.

Because of the differences in underlying assumptions the scenarios produce different outcomes. The results are not predictions, but descriptions of possible future developments on the basis of an applied general equilibrium model of the world economy and various exogenous trends that have been assumed. There seems considerable scope for CIS countries to integrate in the world economy. Continued globalisation may further economic growth, while high economic growth harms the environment. However, energy-saving technologies and environmental legislation may affect the outcomes. 


\section{ENDNOTES}

1 According to Rodrik (2001) economists rank second to astrologers in their predictive abilities.

2 One example is www.destroyimf.org advertising itself as "a web resource for all those mobilising to end the poverty and injustice inflicted by global capitalism". As the spelling suggests the movement seems to be organised by European activists.

3 These regions are the USA, Western Europe, Japan, Rest of the OECD, Eastem Europe, Former Soviet Union, Middle East and North Africa, Sub-Saharan Africa, Latin America, China, South East Asia, and South Asia \& Rest.

\section{REFERENCES}

1 CENTRAL PLANNING BUREAU (1999) Globalization, Intemational Transport and the Global Environment: Four Quantitative Scenarios, Working Paper No. 110, The Hague: CPB.

2 EUROPEAN BANK FOR RECONSTRUCTION AND DEVELOPMENT (1999) Transition Report 1999, London: EBRD.

3 EUROPEAN BANK FOR RECONSTRUCTION AND DEVELOPMENT (2000) Transition Report 2000, London: EBRD.

4 EUROPEAN BANK FOR RECONSTRUCTION AND DEVELOPMENT (2001) Transition Report update April 2001, London: EBRD.

5 LEVITT, T. (1993) "The Globalization of Markets", in: Robert Z. Aliber and Reid W. Click (eds.), Readings in International Business: A Decision Approach, Cambridge/London: The MIT Press.

6 LLOYD, P.J. (1992) Regionalisation and World Trade", OECD Economic Studies, No. 18: 7-43.

7 MADDISON, A. (2001) The World Economy: A Millenial Perspective, Paris: OECD.

8 MUSSA, M. (2000) Factors Driving Global Economic Integration, http://www.imf.org/external/np/speeches/2000/082500.htm.

9 RODRIK, D. (2001) "How Far Will International Economic Integration Go?", Journal of Economic Perspectives, 14(1): 177-186.

10 SCHOLTE, J.A. (1997) Globalization: A Critical Introduction, Basingstoke: Macmillan.

11 WILLIAMSON, J.G. (1996) "Globalization, Convergence and History", Journal of Economic History, 56(2): 277-306.

12 WILLIAMSON, J.G. (1997) "Globalization and Inequality, Past and present", The World Bank Research Observer, 12(2); 117-135. 
13 WORLD TRADE ORGANIZATION (2000) International trade statistics 2000, Geneva: WTO.

14 WORLD TRADE ORGANIZATION (2001) Annual Report, Geneva: WTO. 